\title{
FENOMENA PERKEMBANGAN CROWDFUNDING DI INDONESIA
}

\author{
Arief Yuswanto Nugroho ${ }^{1} \&$ Fatichatur Rachmaniyah $^{2}$ \\ Universitas Islam Darul 'Ulum - Lamongan \\ E-mail : ariefyuswanto@unisda.ac.id ${ }^{1}$ \\ fatichaturrachmaniyah@unisda.ac.id ${ }^{2}$
}

\begin{abstract}
Crowdfunding is an internet-based financial intermediation platform that collects funds from the general public to finance a project or business unit. This study aims to determine the development of crowdfunding in Indonesia, as well as how the development of Indonesian crowdfunding when compared to Asian countries. This Research is a descriptive qualitative study with literature studies. The results of this study can be concluded that the development of crowdfunding platforms in Indonesia is mostly Debt Based. Indonesian society, especially in urban society, they still have not utilized it maximally because there is minimum of literacy related to crowdfunding as alternative funding. The number of crowdfunding in Indonesia compared to other Asian countries, namely India and Malaysia is quite competitive. However, in terms of the percentage level of entrepreneurship, Indonesia is still far behind.
\end{abstract}

Keywords : Crowdfunding, Fintech, Indonesia, Asia.

\begin{abstract}
ABSTRAK
Crowdfunding adalah platform intermediasi keuangan berbasis internet yang mengumpulkan dana dari masyarakat umum untuk membiayai suatu proyek atau unit usaha. Penelitian ini bertujuan untuk mengetahui perkembangan crowdfunding di Indonesia, serta bagaimana perkembangan crowdfunding Indonesia jika dibandingkan dengan Negara Asia. Penelitian merupakan penelitian kualitatif deskriptif dengan studi literatur. Hasil penelitian ini dapat disimpulkan bahwa perkembangan platform crowdfunding di Indonesia mayoritas berjenis Debt Based. Masyarakat Indonesia khususnya pada masyarakat urban masih belum memanfaatkannya dengan maksimal karena masih kurangnya literasi pengetahuan terkait crowdfunding sebagai pendanaan alternatif. Jumlah crowdfunding Indonesia dibandingkan negara-negara Asia lainnya, yaitu India dan Malaysia cukup kompetitif. Namun, dilihat dari segi persentase tingkat wirausaha, Indonesia masih tertinggal cukup jauh.
\end{abstract}

Kata kunci: Crowdfunding, Fintech, Indonesia, Asia.

\section{PENDAHULUAN}

Pada era ini otomatisasi yang terintegrasi dengan internet menjadi kata kunci dalam semua sektor industri yang ada di Indonesia. Kondisi otomatisasi dan era digital teknologi yang terintegrasi dengan internet merupakan awal dimulainya era industry 4.0 yang akan memberikan dampak positif dari sisi ekonomi dan industri. Dari sektor 
ekonomi kecepatan dalam mengakses informasi dan pertukaran data merupakan hal yang sangat membantu dalam proses transaksi dan transparansi di bidang keuangan. Penerapan teknologi informasi dibidang keuangan atau yang dikenal dengan financial technology sangat membantu gaya hidup sosial yang dulu berbasis manual dan membutuhkan waktu yang lama dalam proses transaksi serta pertukaran data informasi menjadi serba otomatis, bisa dilakukan hanya sekian menit saja dan tidak membutuhkan waktu yang lama.

Berbagai produk dari Financial Technology didesain untuk mempermudah masyarakat untuk mengakses produk dari Fintech tersebut baik berupa pinjaman, penghimpunan dana secara kolektif, pembayaran online, permodalan, investasi dan produk fintech lainnya. Penghimpunan dana secara kolektif atau crowdfunding merupakan salah satu produk fintech yang memberikan solutif dalam mengatasi kesulitan ekonomi dalam hal permodalan untuk membangun dan mengembangkan usaha.

Konsep crowdfunding sebenarnya diperuntukkan bagi mereka yang ingin mengembangkan usahanya tetapi terkendala dari sisi permodalannya. Perkembangan teknologi yang cepat dan kemudahan dalam mengakses informasi, pertukaran data serta transaksi via internet seharusnya mampu membuat platform crowdfunding ini lebih cepat berkembang dan dikenal luas oleh masyarakat. Namun, banyak masyarakat Indonesia yang tidak mengetahui tentang informasi tersebut, sehingga wirausaha di Indonesia kurang berkembang. Hal ini yang seharusnya menjadi sumber pendanaan bagi sektor UMKM (Usaha Mikro Kecil Menengah) untuk memperluas dan mengembangkan usahanya. Oleh karena itu, tema terkait perkembangan dan permasalahan crowdfunding di Indonesia menarik untuk dibahas lebih mendalam.

\section{KAJIAN TEORI}

\section{Fintech}

Fintech adalah teknologi keuangan yang merupakan suatu model pelayanan keuangan melalui pengembangan inovasi teknologi informasi. Fintech dengan layanan keuangan seperti crowdfunding, mobile payments, dan lain sebagainya menjadikan revolusi berbagai inovasi dalam perkembangan teknologi.

(Hsueh \& Kuo, 2017) mengungkapkan bahwa adanya perkembangan revolusi fintech yang dipengaruhi oleh revolusi industry yaitu: (a) Revolusi Fintech 1.0, berawal 
dari transformasi informasi global dengan membangun kabel bawah laut trans atlantik tahun 1866. Hal ini mulai diperkenalkannya telex dan diners card sebagai transaksi kredit dengan kartu kredit. (b) Revolusi Fintech 2.0, pemanfaatan teknologi komputer dan data jaringan untuk komunikasi data elektronik seperti mesin ATM yang dicanangkan pertama kali tahun 1967 di Inggris. Otoritas Jasa Keuangan Indonesia mulai melakukan regulasi untuk menjamin transaksi keuangan agar tidak terganggu. (c) Revolusi Fintech 3.0, mulai maju perkembangan bisnis berbasis elektronik dengan menggunakan data jaringan atau system online. (4) Revolusi Fintech 4.0, semakin banyak inovasi-inovasi terbarukan berbasis teknologi dengan sistem online diberbagai sektor, yang meliputi: pembayaran (payment), peminjaman (lending), perencanaan keuangan (personal finance), pembiayaan (crowdfunding), dan lain sebagainya.

Menurut (Hsueh \& Kuo, 2017), Financial technology dapat digolongkan menjadi tiga tipe, yaitu:

a. Third-party payment systems, merupakan sistem pembayaran melalui pihak ketiga. Contoh: sistem pembayaran mobile, platform pembayaran yang menyediakan jasa seperti transfer dan pembayaran bank,

b. Peer to Peer $(P 2 P)$ Lending, merupakan platform yang mempertemukan pihak yang kelebihan dana dengan pihak yang membutuhkan dana melalui internet. Jadi platform ini memberikan jasa kepada kreditur dan debitur untuk membantu memenuhi kebutuhannya masing-masing secara efisien.

c. Crowdfunding, merupakan sebuah konsep suatu program yang dipublikasikan secara umum melalui internet, yang mana jika masyarakat tertarik dengan konsep tersebut akan memberikan dukungan secara finansial, dan investor akan mendapatkan imbalan sesuai kesepakatan.

\section{Crowdfunding}

Konsep crowdfunding sendiri merupakan inspirasi dari konsep micro finance (Morduch, 1999) dan crowdsourcing (Poetz, 2012), tetapi konsep crowdfunding ini memiliki karakter yang unik berbeda dari dua konsep sebelumnya, uniknya konsep crowdfunding ini adalah dalam hal penggalangan dana difasilitasi oleh situs internet (Mollick, 2014). Menurut Hollis and Sweetman, 2011 dalam (Hobbs, Grigore, \& 
Molesworth, 2016) Crowdfunding dalam banyak hal bukan ide yang baru. Hal tersebut, dapat ditelusuri kembali pada tahun 1700-an melalui konsep keuangan mikro. Salah satu contoh yang menonjol adalah Dana Pinjaman Irlandia, yang diprakarsai oleh Jonathan Swift untuk memberikan kredit kepada kaum miskin di negara itu di mana lebih dari $20 \%$ dari semua rumah tangga Irlandia memegang Dana Pinjaman Irlandia. Konsep Pinjaman tersebut memperoleh popularitas dan memuncak pada tahun 1800-an (Svobodov, 2016). Adanya transformasi dari konsep micro finance dan konsep crowdsourcing via Internet melahirkan konsep crowdfunding. Jadi, konsep crowdfunding bukan suatu konsep baru, yang menjadi crowdfunding hal baru itu dikarenakan adanya perkembangan teknologi.crowdfunding didefinisikan sebagai suatu proyek pendanaan didasarkan pada pengumpulan dana dalam jumlah banyak atau sedikit guna peningkatan modal dari suatu inisiatif atau ide melalui internet (Belt, B., C. Brummer, 2012). Menurut (Hui, 2012) mendefinisikan Crowdfunding sebagai permintaan terhadap sumber daya keuangan baik secara online dan offline sebagai imbalannya ditawarkan hadiah, seperti pengakuan, pengalaman, atau produk oleh pencipta proyek tersebut. Menurut (Valanciene, L., \& Jegeleiciute, 2014) menyatakan bahwa Crowdfunding adalah sebuah metode untuk menghubungkan antara entrepreneur yang menginginkan peningkatan modal dan investor yang memiliki sumber dana melalui entitas intermediary berbasis internet.

Berdasarkan beberapa pengertian tersebut dapat disimpulkan bahwa didalam sistem crowdfunding ini, terdapat adanya korelasi antara investor yang memiliki sumber dana terhadap mereka yang mempunyai proyek usaha atau mereka yang mempunyai ide kreatif suatu usaha tertentu yang membutuhkan suatu pooling dana atau permintaan terhadap financial source. Crowdfunding merupakan platform yang dapat diintegrasikan secara praktis di setiap sektor kegiatan ekonomi. Salah satu sektor di mana crowdfunding dapat berperan positif adalah di sektor Usaha Mikro Kecil dan Menengah. Selain dari kredit perbankkan atau modal dari keluarga, crowdfunding dapat menjadi salah satu pembiayaan alternatif bagi starup/UMKM yang efektif dan solutif dalam mengatasi kesulitan dalam mendapatkan pendanaan. Praktek penggalangan dana ini merupakan upaya untuk menghimpun peran atau kontribusi dari masyarakat luas untuk mewujudkan sebuah program atau proyek tertentu yang dilakukan secara online (Kocer, 2014). Jadi, crowdfunding merupakan platform intermediasi keuangan berbasis internet yang 
mengumpulkan dana dari masyarakat umum untuk membiayai suatu proyek atau unit usaha. Crowdfunding sebagai platform untuk menginformasikan proposal suatu proyek ke masyarakat umum yang bertujuan untuk menggalang dana secara online guna merealisasikan atau mensukseskan proyek tersebut.

\section{Gambar 1. Framework crowdfunding}

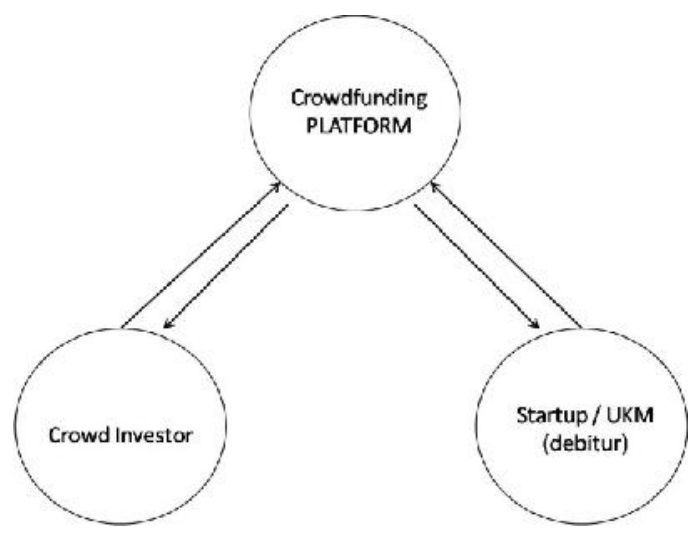

Pada pelaksanaan crowdfunding ini terdapat tiga pelaku utama, antara lain: Pertama, pebisnis startup atau UKM yang membutuhkan modal dengan mengajukan proposal permintaan pendanaan melalui platform crowdfunding. Kedua, platform crowdfunding berperan sebagai intermediasi keuangan yang mencarikan pendanaan kepada crowd investor melalui internet. Ketiga, crowd investor melihat dan menganalisis peluang investasi yang ditawarkan pihak startup/ UKM melalui platform crowdfunding, lalu memberikan komitmennya untuk mendanai program tersebut.

Hal ini pada pihak platform crowfunding juga melakukan review materi promosi penggalangan dana sampai melakukan dokumentasi hukum yang layak terhadap program yang akan ditawarkan oleh pihak startup/UKM, serta melayani jasa dalam mempersiapkan rencana usaha dengan proyeksi keuangan sebagai materi penggalangan dana. Bagi crowd investor yang ingin berpartisipasi dalam program yang ditawarkan pihak startup/UKM tidak akan dikenakan biaya apapun oleh platform crowdfunding, melainkan akan mendapat keuntungan sesuai dengan kesepakatan.

Pada dasarnya konsep crowdfunding merupakan transformatif dari model bisnis yang ada dan dapat diintegrasikan ke dalam empat model, yaitu: (a) Donation Based, Crowdfunding ini digunakan untuk proyek atau program bersifat non-profit, yang berinisiatif sosial dan amal menurut (Hossain, 2017). Hal ini para penyandang tidak mengharapkan keuntungan, tetapi umumnya mereka akan memperoleh imbalan dalam 
bentuk jasa atau barang dari aksi donasi yang mereka lakukan (Forbes, H., \& Schaefer, 2017) Contoh: membantu korban bencana, membangun panti asuhan. (b) Reward based, Proyek atau program yang memberikan penawaran berupa imbalan berupa barang, jasa atau sebuah hak, dalam hal ini bukan memberikan keuntungan dari proyek tersebut. Biasanya crowdfunding jenis ini untuk proyek atau program dari industri kreatif, seperti games, yang mana para donatur akan mendapat imbalan berupa fitur-fitur menarik dari games tersebut. (c) Debt Based, Crowdfunding ini sama dengan pinjaman kredit yang mana pihak startup/UKM (debitur) mengajukan proposalnya dan crowd investor (kreditur) akan menyetorkan modalnya sebagai pinjaman dengan imbalan berupa bunga (Hsueh \& Kuo, 2017). (d) Equity Based, Penyetoran dana crowd investor akan menjadi ekuitas (saham) sebagai kepemilikian atas unit usaha yang diprogramkan oleh startup/UKM tersebut dan hal ini crowd investor akan mendapat imbalan keuntungan dari unit usaha tersebut sesuai presentase penyetoran dana (Bellefllamme, P., T. Lambert, 2013)

\section{METODOLOGI PENELITIAN}

Penelitian ini merupakan penelitian deskriptif kualitatif yang berbasis pada studi literasi dengan mengumpulkan jurnal dan publikasi yang terindeks pada google. Jurnal dan publikasi tersebut merupakan jurnal dan publikasi yang sesuai dengan topik pada penelitian ini. Selain mengumpulkan serta membaca jurnal dan publikasi, peneliti juga mengakses beberapa website internet yang ada kaitannya dengan topik penelitian guna mendapatkan kerangka konsep berpikir dan memahami konteks dari penelitian secara mendalam.

Penggunaan literatur dapat memberikan gambaran baik yang sudah diketahui maupun yang belum diketahui dari suatu fenomena khusus. Penggunaan literature pada penelitian bersifat kualitatif bertujuan untuk mempertahankan kealamiahan data (Afiyanti, 2005) .

\section{PEMBAHASAN}

\section{Fenomena Perkembangan Crowdfunding di Indonesia}

Di Indonesia, pelaku crowdfunding masih sangat terbatas. Berdasarkan data tahun 2017 
dari dewan komisioner OJK pelaku fintech Indonesia masih didominasi oleh bisnis disektor Payment sebesar 43\%, Lending sebesar 17\%, Aggregator 13\%, sisanya berbentuk Personal or financial planning, Crowdfunding, dan lain-lain (Hadad, 2017). Istilah metode crowdfunding mulai dikenal pada tahun 2008 dengan terbentuknya situs crowdfunding Amerika yang merupakan crowdfunidng terbesar di dunia yakni Kickstarter dan Indiegogo. Namun, di Indonesia crowdfunding baru bermunculan pada tahun 2012, antara lain: Wujudkan.com, AyoPeduli.com, Patungan.net, Kitabisa.com, dan GandengTangan.com. Seiring berkembangnya waktu telah bermunculan beberapa crowdfunding, yang tadinya hanya sekitar 6,5 persen meningkat menjadi 93,5 persen.

Tiga diantaranya merupakan jenis crowdfunding Donation Based yaitu AyoPeduli.com, Patungan.net, dan Kitabisa.com. Crowdfunding ini bergerak di bidang sosial non profit, seperti: kesehatan, pendidikan, lingkungan dan budaya. Namun, tidak lama beberapa tahun kemudian beberapa crowdfunding tersebut berhenti beroperasi, kecuali Kitabisa.com. Sampai saat ini, Kitabisa.com masih aktif dalam penggalangan dana dan pernah melakukan transaksi terbesar di Indonesia pada tahun 2016 untuk penggalangan Masjid Chiba yang diprakarsai oleh komunitas muslim Indonesia di Chiba Jepang, di mana menggalang dana sebesar Rp 3,2 milyar.

Wujudkan.com merupakan crowdfunding Reward Based yang bergerak di bidang industri kreatif, seperti film, komik dan games. Crowdfunding ini hanya berumur 5 tahun, di mana pada tahun 2017 ini dinyatakan berhenti beroperasi karena pencapaian target yang tidak maksimal.

GandengTangan.com yaitu crowdfunding jenis Debt Based. Platform ini berfokus untuk pendanaan UKM di Indonesia. Masyarakat yang membutuhkan modal untuk menjalankan atau akan memulai usahanya dapat terbantukan dengan adanya crowdfunding ini, sehingga secara tidak langsung crowdfunding jenis debt dan equity based ini membantu meningkatkan perekonomian masyarakat di Indonesia. UKM yang didanai melalui GandengTangan.com, akan didampingi oleh GT-Trust sebagai mitra yang membantu memajukan usahanya. GandengTangan.com yang berdiri tahun 2017 ini telah berhasil menyalurkan kurang lebih Rp 5 milyar untuk membantu 1.200 UKM yang tersebar di Indonesia. GandengTangan.com juga telah menjadi salah satu crowdfunding 
penerima hibah dari DBS Foundation Social Enterprise Grant Programme 2018 Singapore.

Berdasarkan data AlliedCrowds terdapat 14 platform crowdfunding yang aktif di Indonesia, sebanyak 10 platform diantaranya mayoritas berjenis Debt Based Hal ini menunjukkan bahwa adanya perkembangan platform pendanaan yang akan berdampak pada kemajuan UMKM di Indonesia.

\section{Kurangnya literasi terhadap crowdfunding di Indonesia}

Kurangnya literasi mengenai crowdfunding kemungkinan menjadi salah satu penyebab rendahnya partisipasi masyarakat Indonesia terhadap crowdfunding, sehingga mengakibatkan perkembangan crowdfunding di Indonesia cenderung lambat. Ketergantungan terhadap perbankan atau bisa disebut sebagai industri financial konvensional lebih banyak diminati oleh masyarakat Indonesia dibandingkan dengan platform crowdfunding. Ketika masyarakat membutuhkan modal untuk membuka usaha atau tiba-tiba memiliki ide inovatif untuk memulai usaha, mereka akan mengajukan pinjaman modal dalam bentuk kredit kepada sektor perbankan.

Berdasarkan hasil survey yang dilakukan setiap tahun oleh Asosiasi Penyelenggara Jasa Internet Indonesia (APJII) menemukan banyak temuan menarik mengenai potret penetrasi dari pengguna internet di Indonesia, yaitu: pertama, Hasil dari survey pengguna internet terkonsentrasi di pulau Jawa masih mendominasi pengguna internet sebesar 58,08\%, sementara Sumatera sebesar 19,09\%, Kalimantan sebesar 7,97\%, Sulawesi sebesar 6,73\%, Bali-Nusa sebesar 5,63\% dan Maluku-Papua 2,49\%. Kedua, Hasil dari survey pengguna internet terkonsentrasi di wilayah urban sebanyak $72,41 \%$, rural urban sebesar 49,49\% dan rural hanya 48,25\%. Ketiga, Hasil dari survey pengguna internet pengguna internet di Indonesia mengakses aplikasi chatting sebanyak $89,35 \%$, media social $87,13 \%$, mesin pencari sebesar $74,84 \%$, melihat gambar/foto $72,79 \%$, melihat video $69,64 \%$ dan sisanya aktivitas internet lain sebanyak 7,39\% responden yang mengakses layanan perbankan via internet. Keempat, Hasil dari survey pengguna internet di Indonesia didominasi pada umur 15-24 sebesar 58,21\%.

Pemaparan data yang dihasilkan oleh APJII dapat ditarik kesimpulan bahwa akses penetrasi internet hanya berkutat pada chatting, media social dan lain-lain, untuk 
pencarian informasi, edukasi dan literasi via internet masih belum menjadi hal yang utama. Hal tersebut menunjukkan bahwa pola pikir digital masyarakat Indonesia dalam mencari literasi edukasi masih belum terbangun. Hal ini diperkuat oleh pendapat Kepala Kebijakan Publik Facebook, Rubben Hattari dalam (Yusuf, 2018) menyatakan bahwa sebagian masyarakat Indonesia yang menggunakan internet masih fokus terhadap media social dan belum berfokus pada pemahaman yang lebih maju.

Proporsi penggunaan internet di Indonesia masih di dominasi wilayah perkotaan hal ini dikarenakan akses fiber optic dan infrastruktur yang mendukung jaringan internet lebih memadai dibandingkan daerah lainnya khususnya pedesaan. Hal ini membuat akses terhadap informasi, edukasi dan literasi dalam bidang keuangan via internet masih belum optimal di Indonesia. Adanya hambatan dalam mengakses informasi, edukasi dan literasi via internet terkait pengetahuan dan pemahaman terhadap produk keuangan menjadi salah satu penyebab rendahnya partisipasi masyarakat Indonesia terhadap crowdfunding, sehingga mengakibatkan perkembangan crowdfunding di Indonesia lambat.

Survey terhadap literasi dan inklusi yang dilakukan oleh Otoritas Jasa Keuangan di Indonesia menyebutkan bahwa masyarakat di Indonesia memiliki indeks literasi keuangan hanya $21.84 \%$. Kondisi tersebut memang sangat memprihatinkan ketika dihadapkan pada kemampuan untuk menggunakan pengetahuan dan keterampilan seseorang untuk mengelola sumber daya keuangan secara efektif ternyata masih belum optimal.

\section{Perbandingan Perkembangan Crowdfunding Indonesia dengan Negara Asia}

Menurut SME Finance Forum (Forum Keuangan UKM) ada kesenjangan kredit UMKM \$ 2,3 triliun di Asia Timur dan Pasifik. Sebenarnya pendanaan crowdfunding dapat membantu mengatasi kesenjangan ini, dengan menawarkan perorangan dan usaha kecil untuk mendapat sumber pendanaan alternative dalam bentuk crowdfunding yang berbasiskan donasi, equity dan pinjaman (peer-to-peer atau peer-to-business). Pendanaan crowdfunding sangat penting bagi Negara Berkembang, karena mereka memiliki UMKM yang masih membutuhkan pendanaan untuk mengembangkan bisnisnya menjadi lebih baik. Perkembangan konsep pendanaan crowdfunding di Indonesia sendiri diharapkan mampu mengairahkan gejolak pertumbuhan perekonomian kita, tetapi masih banyak 
masyarakat kita yang masih belum begitu mengenali konsep ini. Hal ini merupakan permasalahan yang sering dihadapi oleh negara Asia termasuk Indonesia.

Berdasarkan data dalam AlliedCrowd tahun 2018, di Indonesia terdapat 61 platform crowdfunding, 14 diantaranya berstatus aktif dan 47 tidak aktif atau jika dipersentasikan hanya $21 \%$ yang statusnya masih aktif sedangkan yang tidak aktif sebesar 79\%. Jika dibandingkan dengan Negara-negara di Asia seperti India, Malaysia, Philipina, Pakistan, Vietnam, Thailand, Bangladesh, Turkey, Cambodia, Jordan, Nepal, Armenia, dan Libanon. Indonesia termasuk paling banyak memiliki platform crowdfunding, tetapi karena kurangnya literasi terhadap platform crowdfunding ini membuat partisipasi masyarakat di Indonesia menjadi kurang sehingga mengakibatkan banyak platformplatform ini yang tadinya aktif menjadi tidak aktif.

Tabel 1 Daftar Crowdfunding yang Aktif di Negara India, Malaysia, Indonesia

\begin{tabular}{|c|c|c|c|}
\hline No. & INDIA & MALAYSIA & INDONESIA \\
\hline 1 & Impact Guru & Alix Global & Akseleran \\
\hline 2 & Ketto & CROWDO & Amartha.Microfinance \\
\hline 3 & Lendbox & CrowdPlus.Asia & CROWDO \\
\hline 4 & Lenden Club & Eureeca & DANAdidik \\
\hline 5 & Letz Change & Impact Guru & Gandeng Tangan \\
\hline 6 & Loanmeet & Kapital Boost & Impact Guru \\
\hline 7 & Milaap & PitchIN & Investree \\
\hline 8 & Monexo & SimplyGiving.com & Kapital Boost \\
\hline 9 & Omnivore Partners & SkolaFunding & Koinworks \\
\hline 10 & Peer Lend & & Kopernik \\
\hline 11 & Quick Credit.In & & Kitabisa \\
\hline 12 & Rang De & & Modalku \\
\hline 13 & seedX & & Sinwattana \\
\hline 14 & Vole for Cash & & \\
\hline 15 & Whitengel & & \\
\hline 16 & Wishberry & & \\
\hline
\end{tabular}

Sumber data: olahan (alliedcrowds, 2018)

Dari 14 negara Asia dalam data AlliedCrowds tersebut, jumlah crowdfunding yang berstatus aktif di Indonesia dibandingan dengan Negara India dan Malaysia cukup kompetitif. Namun, jika dilihat dari efek hasil crowdfunding pada segi tingkat wirausaha, Indonesia masih tertinggal cukup jauh dengan India dan Malaysia. Di India, saat ini telah memiliki pertumbuhan ekonomi yang kuat dan telah sukses meningkatkan dan 
menghasilkan wirausahawan baru, yang mana tingkat wirausaha di India sebesar 7 persen (CNBC Indonesia). Sedangkan di Malaysia, tingkat wirausaha mencapai sebesar 5 persen dari total jumlah penduduknya.

Meskipun Malaysia hanya memiliki sembilan platform crowdfunding yang aktif, mereka mampu meningkatkan rasio persentase wirausaha lebih tinggi dibandingkan dengan Indonesia. Pertumbuhan pengusaha baru di Indonesia cukup lambat jika dibandingkan dengan Negara India dan Malaysia, yang mana pada tahun 2016 tercatat sebesar 1 persen dan tahun 2018 pertumbuhannya hanya mencapai 3,1\% dari populasi penduduk Indonesia. Oleh karena itu, permasalahan ini yang dihadapi Indonesia akan bisa teratasi dengan pendanaan alternatif, crowdfunding, guna meningkatkan atau menambah modal untuk pengembangan usaha baru. Seharusnya sektor UMKM Indonesia lebih banyak menggunakan platform tersebut dalam hal pengembangan usaha. Penggunaan teknologi internet yang berbasis pada social media seperti chatting, melihat gambar dan video membuat tingkat literasi terhadap perkembangan teknologi keuangan di masyarakat Indonesia kurang, sehingga sosialisasi yang digalakkan oleh otoritas jasa keuangan terkesan belum efektif.

\section{SIMPULAN \& SARAN}

\section{Simpulan}

Konsep crowdfunding merupakan cara organisasi atau individual untuk mengumpulkan dana dalam bentuk sumbangan dari banyak individu untuk meraih tujuan dari sasaran yang di sepakati melalui internet. Ketepatan dalam penggunaan dan penguasaan teknologi internet dalam proses bisnis, termasuk teknologi seluler,media social dan investasi crowdfunding di Negara berkembang seperti Indonesia seharusnya bisa memajukan sektor Usaha Mikro Kecil dan Menengah dalam menerapkan system pendanaan kewirausahaan yang lebih efisien dan efektif.

Pertumbuhan UMKM memang diharapkan mampu mendorong pertumbuhan ekonomi di Indonesia. Tetapi banyak faktor dan kendala yang dihadapi oleh pengusaha di sector ini, salah satunya adalah permasalahan dana untuk memulai dan mengembangkan usaha. Ketidak tahuan atau kurangnya literasi terhadap konsep crowdfunding ini membuat banyak pengusaha masih mengandalkan konsep konvensional 
yakni pengajuan kredit untuk penambahan modal pada sector keuangan konvensional yakni industry perbankan.

\section{Saran}

Berdasarkan pemaparan di atas, peneliti menyarankan kepada pemerintah untuk mendukung dalam pembentukan "gerakan literasi keuangan" untuk menambah wawasan kepada masyarakat urban tentang berbagai pendanaan, khususnya pendanaan dengan crowdfunding. Dalam hal ini pemerintah bisa bekerja sama dengan perguruan tinggi, dalam bentuk pengabdian masyarakat untuk mensosialisasikan kepada masyarakat urban.

Untuk peneliti selanjutnya bisa mengembangkan konsep dari crowdfunding ini dengan menambahkan beberapa variable atau menggunakan metode penelitian kualitatif dan kuantitatif sehingga bisa dihasilkan penelitian yang lebih sempurna lagi.

\section{DAFTAR PUSTAKA}

Afiyanti, Y. (2005). PENGGUNAAN LITERATUR DALAM PENELITIAN KUALITATIF. Keperawatan Indonesia, 9(No 1). Retrieved from http://jki.ui.ac.id/index.php/jki/article/view/157

Alliedcrowds. (2018). Crowdfunding in Asia. Retrieved from https://alliedcrowds.com/static/reports/AlliedCrowds-Crowdfunding-in-AsiaDirectory.pdf

Bellefllamme, P., T. Lambert, and A. S. (2013). Individual Crowdfunding Practices. An International Journal of Entrepreneurial Finance, 15, 313-333.

Belt, B., C. Brummer, and D. G. (2012). Crowdfunding: Maximizing the Promise and Minimizing the Peril. Washington, DC: Milken Institute. Retrieved from https://assets1b.milkeninstitute.org/assets/Publication/ResearchReport/PDF/crowdf unding 120827.pdf

BPS. (2016). Proporsi Individu Yang Menggunakan Internet Menurut Daerah Tempat Tinggal, 2015 - 2016. Retrieved January 29, 2019, from https://www.bps.go.id/dynamictable/2018/05/21 00:00:00/1352/proporsi-individuyang-menggunakan-internet-menurut-daerah-tempat-tinggal-2015---2016.html

Forbes, H., \& Schaefer, D. (2017). Guidelines for Successful Crowdfunding. Retrieved February 5, 2019, from https://researchportal.bath.ac.uk/en/publications/guidelinesfor-successful-crowdfunding

Hadad, M. D. (2017). Financial Technology (FinTech) di Indonesia. Retrieved from http://www.ibs.ac.id/img/doc/MDH - FinTech IBS June 2017.pdf

Hobbs, J., Grigore, G., \& Molesworth, M. (2016). Success in the management of crowdfunding projects in the creative industries. Internet Research, 26(1), 146-166. https://doi.org/10.1108/IntR-08-2014-0202 
Hossain, M. and G. O. O. (2017). Crowdfunding: Motives, Definitions, Typology and Ethical Challenges. Entrepreneurship Research Journal.

Hsueh, S.-C., \& Kuo, C.-H. (2017). Effective Matching for P2P Lending by Mining Strong Association Rules. In Proceedings of the 3rd International Conference on Industrial and Business Engineering - ICIBE 2017 (pp. 30-33). New York, New York, USA: ACM Press. https://doi.org/10.1145/3133811.3133823

Hui, J. E. G. and M. G. (2012). Easy Money? The Demands of Crowdfunding Work.

Kocer, S. (2014). Sosial Business in Online Financing: Crowdfunding Narrative of Independent Documentary Producer in Turkey. SAGE, 17(2), 231-248. Retrieved from https://journals.sagepub.com/doi/abs/10.1177/1461444814558913

Mollick, E. (2014). The Dynamics of Crowdfunding: an Exploratory Study. Journal of Business Venturing, 29 (1), 1-16.

Morduch, J. (1999). The Microfinance Promise. Journal of Economic Literature, XXXVII, 1569-1614. Retrieved from https://wagner.nyu.edu/files/faculty/publications/199912 Microfinance_Promise.pdf

Poetz, M. K. M. S. (2012). The value of crowdsourcing:Can users really compete with professionals in generating new product ideas? Journal of Product Innovation Management, 245-256. from https://www.cbs.dk/files/cbs.dk/download2.pdf

Svobodov, I. (2016). THE LEVEL OF RESEARCH CZECH CROWDFUNDING, 17691776.

Valanciene, L., \& Jegeleiciute, S. (2014). Crowdfunding for creating value: stakeholder approach. Precedia-Social and Behavioral Sciences, 599-604.

Yusuf. (2018). Antisipasi Potensi Konflik di Media Sosial, Kominfo Prioritaskan Edukasi. Retrieved February 14, 2019, from https://www.kominfo.go.id/content/detail/14687/antisipasi-potensi-konflik-dimedia-sosial-kominfo-prioritaskan-edukasi/0/berita_satker 